\title{
Penggunaan Teknik Aversi Berkondisi untuk Meminimalisir Conduct Disorder untuk Tunagrahita
}

\author{
Khusnul Khotimah, Mohammad Efendi, Asep Sunandar \\ Universitas Negeri Malang \\ E-mail: khus21kho@gmail.com
}

\begin{abstract}
Abstrak: penelitian ini bertujuan untuk mengetahui perubahan perilaku conduct disorder sebelum dan sesudah diberikan intervensi serta mengetahui efektivitas teknik aversi berkondisi. Subjek adalah siswa kelas 3 dengan hambatan intelektual yang mempunyai perilaku sering berbicara kotor. Penelitian ini menggunakan metode ekperimen yaitu Single Subjek Research (SSR) dengan desain multiple cross conditions. Pencacatatan dilakukan dengan pencatatan waktu banyaknya subjek berbicara kotor dalam waktu 30 menit. Hasil akan di analisis menggunakan mean, level, latency dan trend. Perhitungan data menunjukkan adanya penurunan pada setiap garfik di masing-masing kondisi. Dapat disimpulkan bahwa teknik aversi berkondisi efektif untuk meminimalisir perilaku conduct disorder subjek dengan hambatan intelektual
\end{abstract}

Kata Kunci: tunagrahita, teknik aversi berkondisi, conduct disorder

\begin{abstract}
: this research aims to determine change conduct disorder behavior before and after given intervention and know the effectiveness of conditioned aversion technique. Subject was grade 3 student with intellectual disability that have often dirty speech behavior. This research uses experimental method that is Single Subject Research (SSR) with multiple cross conditions design. The record use by recording the time the number of subjects speaks dirty within 30 minutes. Results will be analyzed using the mean, level, latency and trend. The data calculations indicate a decrease in each garfic in each condition. It can be concluded that aversion technique is effective to minimize conduct disorder behavior of subject with intellectual disability.
\end{abstract}

Key Words: Intelectual disability, conditioned aversive technique, conduct disorder

Bahasa disetiap individu begitu beragam tergantung dengan daerah asal. Berbahasa secara lisan dapat diartikan dengan berbicara. Menurut Efendi (2010) mengemukakan bahwa berbicara adalah adalah kegiatan yang dilakukan oleh manusia dan untuk manusia meskipun kegiatan bicara yang dilakukan oleh makhluk hidup selain manusia belumlah bisa dikatakan sebagai bicara. Dalam berbicara perlulah memperhatikan beberapa komponen yang mendukung. Merurut Henry Guntur Tarigan (2013) menjelaskan bahwa "baik membaca maupun berbicara, harus memperhatikan komponen-komponen yang sama, yaitu:struktur kata/bahasa, kosa kata, kecepatan/ kelancaran umum". Pemenuhan akan kompenenkomponen dalam berbicara tentunya akan dipengaruhi oleh beberapa faktor yang mendukung diantaranya adalah pengalamn intelegensi dan lingkungan sekitar. Intelegensi adalah faktor yang sangat penting dalam kemampuan berbicara seseorang. Hal tersebut didukung oleh pendapat Santrock (2014) bila tes kecerdasan menunjukkan dibawah 70 akan sulit bagi individu untuk beradaptsi dengan lingkungan sosial.

Fakta yang terjadi dilapangan mendapatkan tidak semua individu mempunyai kemampuan intelegensi yang baik. Individu yang mempunyai kekurangan dalam intelegensi termasuk pada anak berkebutuhan khusus yang tergolong dalam tunagrahita. Menurut PP No. 72 Tahun 1991 dalam Nunung Apriyanto (2012:21) menjelaskan bahwa "anak-anak dibawah kelompok normal dan atau lebih lamban daripada anak normal, baik perkembangan sosial maupun kecerdasannya disebut anak terbelakang mental: istilah resminya di Indonesia adalah tunagrahita". Salmiah (2010) berpendapat bahwa seseorang dapat dikatakan sebagai tunagrahita bila memenuhi 3 kritiria diantaranya adalah (1) fungsi intelektual dibawah normal, (2) terdapat kendala terhadap perilaku adaptif sosial dan (3) gejala akan timbul pada masa perkembangan yaitu pada usisa dibawah 18 tahun. Keterbatan yang dimiliki tunagrahita tentunya akan berdampak terhadap berbagai hal salah satunya adalah bahasa. Menurut Efendi (2006) dalam bahwa bahasa yang diterima baik verbal ataupun nonverbal akan sulit untuk ditransfer oleh anak tunagrahita. Oleh karenanya banyak kata yang tidak diketahui artinya oleh anak tunagrahita namun diucapkan olehnya sehingga muncullah perilaku berbicara kotor. 


\section{Gambar 1 Format Desain Multiple BaselineCross Condition}

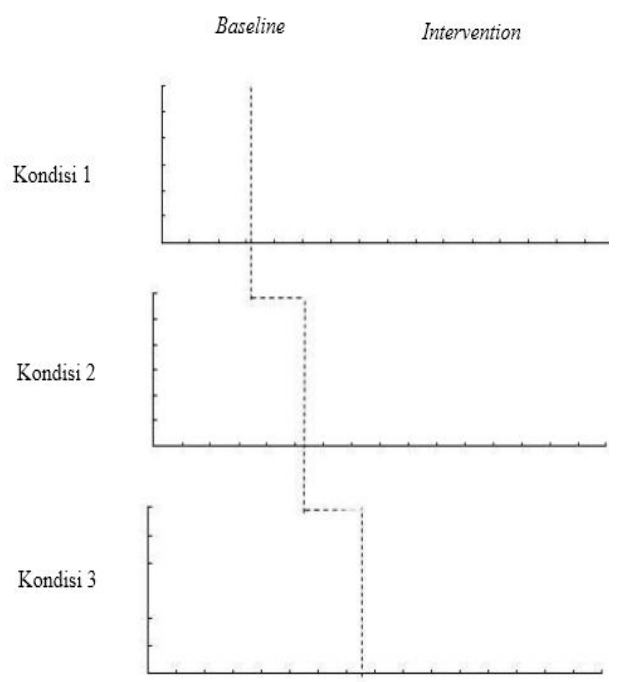

Keterangan :

1. Baseline adalah pengumpulan data pada perilaku sasaran sebelum dikenai intervention.

2. Intervention adalah perlakuan yang dipilih untuk mengubah perilaku sasaran. Intervention berlanjut sampai kriteria untuk perilaku sasaran mencapai trend yang turun.

3. Kondisi adalah situasi dimana yang akan dijadikan pengukuran perilaku anak

Perilaku berbicara kotor didapatkan dari pengaruh lingkungan sekitar. Berdasarkan teori Albert Bandura yang dikenal dengan teori pembelajaran sosial (Social Learning Teory). Teori ini menyatakan pentingnya faktor sosial, faktor perilaku dan faktor kognitif dalam pembelajaran. Dalam eksperimennya yang sering dikenal dengan eksperimen Bobo Doll, Bandura menggunakan dua anak kecil yang ditempatkan di laboraturium namun dengan kondisi yang berbeda. Anak pertama berada pada ruangan dengan boneka yang telah diikat. Sedangkan anak kedua berada pada ruangan dan diperlihatkan film action. Setelah beberapa saat dapat dilihat hasilnya bahwa anak pertama hanya diam dengan memperhatikan boneka dan anak kedua berperilaku yang sama seperti yang ada pada film action. Dapat diambil kesimpulan bahwa perilaku akan terbentuk dikarenakan lingkungan disekitar.

Salah satu permasalahan yang terjadi dilapangan yang ditemukan oleh peneliti adalah kondisi anak yang tidak bisa mengandalikan diri dalam hal komunikasi. Ketidakmampuan mengendalikan diri sering disebut juga dengan conduct disorder. Menurut Tombokan Rantukahu (2013) menjelaskan bahwa, conduct disorder adalah gangguan perilaku seperti berkelahi, memukul, menyerang orang lain, menantang, pemarah suka bertengkar, mencuri dan kejam. Anak sering berkomunasi dengan menggunakan bahasa yang kurang baik (kotor). Anak adalah salah satu siswi di SDLB Negeri Kedungkandang kelas 3. Anak berinisial "S". $\mathrm{S}$ duduk dibangku kelas 3. S mempunyai karakteristik periang, mempunyai kebiasaan berperilaku conduct disoder dan mudah bosan dengan apa yang dilakukan. Kebiasaan conduct disorder yang dimiliki oleh $\mathrm{S}$ ini didapatkan karena ia sering bermain dengan orang yang lebih tua darinya dan dengan mudahnya S meniru semua kata-kata yang ada diucapkan oleh orang yang lebih tua darinya. Hal ini sejalan dengan pendapat dari Jenny Ghicara (2006) mengatakan bahwa kata kasar atau kotor akan timbul jika anak merasa terganggu, tersakiti ataupun karena ia mendapatkan pengalaman dari lingkungnganya.

Sehingga, perlu untuk diberikan solusi agar perilaku tidak berdampak pada pergaluan dikedepannya dan tidak menyebar ke teman sebaya anak. Adapun penelitian Soni Anggara (2016) dengan judul "Efektifitas Prosedur Aversi Untuk Mengurangi Perilaku Menyimpang Anak Tunagrahita Ringan Di SDLB Amal Bhakti Sicincin" menjelaskan bahwa ada perubahan yang signifikan terhadap perilaku onani yang ditimbulkan anak tunagrahita ringan dengan menggunakan teknik aversi. Perilaku onani adalah perilaku seksual mandiri. Pemberian teknik aversi dilakukan yaitu dengan memberikan balsem kepada anak. Dengan intervention tersebut dapat disimpulkan bahwa teknik aversi dapat mengurangi perilaku menyimpang anak.

Berdasarkan hasil observasi intervention bila anak melakukan perilaku conduct disorder yang dilakukan oleh guru kelas adalah dengan teguran. Teguran diberikan dengan kalimat yang halus. Misalkan bila anak melakukan conduct disorder maka guru akan menegur dengan kalimat-kalimat yang halus seperti "Ayo, anak baik duduknya dikursi!", "Ibu akan menelpon ayah yaa", "Ayo dikerjakan tgasnya anak cantik!" dan lain sebagainya. Guru belum melakukan intervention terhadap masalah yang dialami anak dengan teknik tertentu. Oleh karenanya peneliti akan memaparan solusi alternatif yaitu modifikasi perilaku menggunakan teknik aversi berkondisi.

Berdasarkan hasil observasi di lapangan dan penelitian terdahulu maka, peneliti akan menggunakan teknik aversi berkondisi untuk meminimalisir perilaku conduct disorder. Teknik aversi berkondisi adalah prosedur pemberian hukuman yang karena pengalaman yang telah teradi sebelumnya.

\section{METODE}

Metode penetian ini adalah eksperimen Single Subjek Research (SSR) dengan desain multiple baseline cross condition. Menurut Alberto \& Troutman (2009) desain multiple baseline cross conditions adalah 
perilaku sama yang ditunjukkan subjek pada dua atau lebih kondisi. Pada penelitian desain multiple baseline cross conditions ini peneliti ingin mengubah perilaku yang akan menjadi target behavior. Target behavior dalam penelitian ini adalah meminimalisir perilaku conduct disorder anak. Meminimalisir perilaku conduct didorder yang dimaksudkan adalah anak tidak melampaui batas berperilaku conduct disorder dalam waktu yang telah ditentukan. Penelitian akan dilakukan dalam tiga situasi yaitu pada pembelajaran pertama, kedua dan ketiga. Berikut adalah gambaran dari desain multiple baseline cross conditions (Alberto \& Troutman, 2009):

Kondisi yang diamati adalah pada 3 kondisi, yaitu (1) kondisi pertama adalah pembelajaran pertama, (2) kondisi kedua adalah pembelajaran kedua setelah istirahat pertama dan (3) kondisi ketiga adalah pembelajaran ketiga setelah istrahat kedua. Pencatatan variabel dilakukan dengan cara pencatatan kejadian (frekuensi). Pencatatan kejadian (frekuensi) dilakukan dengan waktu yang sama atau konstan yaitu 30 menit pada masing-masing kondisi.

Implementasi pemberian teknik aversi berkondisi haruslah diikuti oleh prosedur lainnya, olej karenanya peneliti akan menggunakan pemberian hukuman decision making. Hal ini diperkuat dengan pernyataan Rantukulu (2013) bahwa penggunaan teknik hukuman dianjurkan untuk menggabungkan dengan prosedur lain misalkan model hukuman decision making atau pemberian pengukuh positif. Pemberian hukuman decision making akan diberikan dengan cara pengkondisian kelas dikarenakan sekolah mempunyai peranan penting dalam membangun emosi anak. Hal ini diperkuat oleh pendapat Mahabbati (2014) bahwa gangguan perilaku dapat semakin meningkat pada usia akademik dikarenakan situasi akademik dan sosial disekolah membutuhkan kontrol perilaku dan emosi.

Teknik aversi berkondisi diterapakan dengan model pemberian hukumamn decision making dimana langkah pertama yang dilakukan adalah pengkondisian kelas dan pemberian tugas yang dapat menarik perhatian siswa. Setelah itu bila perilaku tetap muncul akan diberikan teknik aversi berkondsi. Teknik aversi berkondisi yang digunakan adalah adalah hukuman verbal dan non verbal. Hukuman verbal diantaranya adalah perkataan tegas didekat anak dan perkataan tegas satu anak berpengaruh kesemua. Sedangkan hukuman non verbal diantaranya adalah tatapan dan eksprei tajam

Data yang dihasilkan pada penelitian ini adalah data kuantutatif yang akan disebar dalam bentuk tabel maupun grafik. Kemudian diolah menggunakan analisis visual garfik. Aalisis visual garfik, yaitu dengan cara memasukkan data data kedalam grafik, kemudian data dianalisis berdasarkan komponen mean, level, trend dan latency.

\section{HASIL DAN PEMBAHASAN}

\section{Hasil}

Pengambilan data ini dilakukan dengan menggunakan pencatatan kejadian yang dilakukan oleh peneliti. Data yang dihasilkan akan menunjukkan penurunan dan peningkatan akan perilaku conduct disorder subjek dalam 3 kondisi yaitu kondisi kesatu (pembelajaran kesatu), kondisi kedua (pembelaran kedua) dan kondisi ketiga (pembelajaran ketiga).

Rata-rata yang terjadi pada setiap kondisi menunjukkan perubahan yang signifikan. Pada kondisi kesatu menunjukkan fase baseline memiliki rata-rata 11 sedangkan pada fase intervention menunjukkan angka 5. Pada kondisi kedua rata-rata berada pada angka 12 pada fase baseline dan 3 pada fase intervention. Sedangkan pada kondisi ketiga ratarata menunjukkan angka 11 pada fase baseline dan 3 pada fase intervention. Berdasarkan data tersebut menunjukkan adanya perubahan yang signifikan antara fase baseline dan intervention. Perubahan tersebut terjadi karena penurunan perilaku conduct disorder subjek. Berikut adalah perhitungan rata-rata (Mean) pada masing-masing kondisi

\section{Level}

Berdasarkan data perolehan dapat dilihat bahawa pada kondisi kesatu cenderung stabil tidak ada kenaikan maupun penurunan. Hal ini bukan dikarenakan tidak adanya efektifitas akan intervention namun level perubahannya tetap. Meskipun level perubahan tetap namun hasil pada fase intervention akhir menunjukkan perubahan yang signifikan. Pada kondisi kedua terdapat perubahan sebanyak 10 dengan tanda negatif. Hal ini menunjukkan adanya penurunan sebanyak 10. Sedangkan pada kondisi ketiga terlhat penurunan sebanyak 3. Setelah dilakukannya intervention terlihat perubahan kearah negatif yang mengindikasikan penurunan akan perilaku subjek setelah diberikannya intervention dengan menggunakkan teknik aversi berkondisi berkondisi.

Dapat dilihat dari grafik trend pada fase baseline kondisi pertama garis mengalami penurunan. Sedangkan pada fase intervention juga mengalami penurunan. Hal ini mengidentifikasikan bahwa terjadi pengaruh pada perilaku subjek. Meskipun level menunjukkan pada tingkat stabil tidak ada penurunan. Namun pada fase intervention terakhir terjadi penurunan yang signifikan. Trend pada kondisi kedua menunjukkan penurunan walaupun tidak signifikan pada fase baseline maupun pada fase intevensi. Tingkat level pada kondisi dua mengalami peruanhan yang signifikan. Sedangkan pada kondisi ketiga garis trend tetap mengalami penurunan walaupun tidak sebanyak dikondisi kesatu. Penurunan level pada kondisi ini juga cukup signifikan. 
Tabel 1 Jumlah Perilaku Conduct disorder Fase Multiple BaselineCross Condition Kondisi Pertama

Perilaku Conduct Disorder Fase Multiple Cross Condition

\begin{tabular}{lllll}
\hline Fase & Sesi & $\begin{array}{l}\text { Frekuensi i } \\
\text { Waktu }\end{array}$ & $\begin{array}{l}\text { Peralaku } \\
\text { Conduct } \\
\text { Disorder }\end{array}$ & $\begin{array}{l}\text { Rat a - } \\
\text { Rata }\end{array}$ \\
\hline A & 1 & $08.00-08.30$ & 14 & 11 \\
& 2 & $08.00-08.30$ & 14 & \\
& 3 & $08.00-08.30$ & 13 & \\
& 4 & $08.00-08.30$ & 10 & \\
& 5 & $08.00-08.30$ & 9 & \\
& 6 & $08.00-08.30$ & 8 & \\
& 1 & $08.00-08.30$ & 8 & \\
& 2 & $08.00-08.30$ & 5 & \\
& 3 & $08.00-08.30$ & 6 & \\
& 4 & $08.00-08.30$ & 5 & \\
& 5 & $08.00-08.30$ & 2 & \\
\hline
\end{tabular}

Tabel 2 Fase Multiple BaselineCross Condition Kondisi Kedua

\begin{tabular}{|c|c|c|c|c|}
\hline \multicolumn{5}{|c|}{$\begin{array}{c}\text { Perilaku Conduct Disorder Fase Multiple } \\
\text { Baseline Cross Condition }\end{array}$} \\
\hline Fase & Sesi & $\begin{array}{l}\text { Frekuensi } \\
\text { Waktu }\end{array}$ & $\begin{array}{l}\text { Perilaku } \\
\text { Conduct } \\
\text { Disorder }\end{array}$ & $\begin{array}{l}\text { Rata- } \\
\text { Rata }\end{array}$ \\
\hline \multirow[t]{7}{*}{$\bar{A}$} & 1 & $09.30-10.00$ & 13 & 12 \\
\hline & 2 & $09.30-10.00$ & 13 & \\
\hline & 3 & $09.30-10.00$ & 12 & \\
\hline & 4 & $09.30-10.00$ & 12 & \\
\hline & 5 & $09.30-10.00$ & 10 & \\
\hline & 6 & $09.30-10.00$ & 11 & \\
\hline & 7 & $09.30-10.00$ & 13 & \\
\hline \multirow[t]{4}{*}{ B } & 1 & $09.30-10.00$ & 3 & 3 \\
\hline & 2 & $09.30-10.00$ & 4 & \\
\hline & 3 & $09.30-10.00$ & 5 & \\
\hline & 4 & $09.30-10.00$ & 2 & \\
\hline
\end{tabular}

Dengan adanya grafik trend diatas menunjukkan keefektifan dari penggunaan teknik aversi berkondisi untuk meminimalisir perilaku conduct disorder subjek.

\section{Pembahasan}

Perilaku conduct disorder adalah perilaku yang tidak bisa mengendalikakan diri. Menurut Edi Purwanta (2015) yang termasuk daam perilaku Conduct disorder adalah pemarah, berbiacara kasar, sering memukul, suka iri dan lain-lain. Pada anak tunagrahita mereka cenderung berbicara berdasarkan apa yang mereka lihat. Tunagrahita tidak dapat berfikir secara abstrak. Dasiningrum (2016) mengatakan bahwa anak tunagrahita memiliki ciri-ciri salah satunya adalah kekurangan dalam penyesuaian tingkah laku (perilaku adaptif).

Berdasarkan persebaran data table 1, 2, 3 selanjutnya akan dilakukan dengan analisis data dengan visual grafik. Pada data diatas tidak terlihat adanya latency atau peningkatan. Hal ini dikarenakan pada pengamatan ini akan mengamati penurunan perilaku yang teradi pada subjek. Pada perhitungan trend akan menunukkan adanya perubahan atau penurunan yang terjadi pada perilaku subjek. Grafik trend akan disaikan pada gambar 1 .

Perilaku Conduct disorder memanglah banyak macamnya namun dalam penelitian ini akan terfokus pada berbicara kasar atau kotor yang dilakukan oleh subjek. Berbicara adalah bagian terpenting dalam melakaukanhubunga sosial. Dalam berbicara mememiliku aturan penggunaan bahasa ataupun kata yang harus diperhatikan. Menurut Tarigan (2013) menjelaskan bahwa "baik membaca maupun berbiacara harus memperhatikan komponen-komponen yang sama, yatu: struktur kata/bahasa, kosa kata, kecepata/ kelancaran umum."

Perilaku conduct disorder subjek dapat dilihat pada pengamatan sebelum dilakukannya intervention yaitu pada fase baseline. Berbicara kotor yag dilakkan anak adalah "Tak Paten lo!", "Dobol" "Goblok" dan lain sebagainya. Subjek sering kali menggunakan kata seperti itu ketika sedang berbicara baik dalam keadaan bercanda ataupun marah. Kebiasaaan berbicara kotor yang dimiliki oleh subjek dengan hambatan tunagrahita didapatkan karena pengaruh lingkungan yang ada disekeliling subjek. Hal ini sejalan dengan pendapat dari Ghicara (2006) mengatakan bahwa kata kasar atau kotor akan timbul jika anak merasa terganggu, tersakiti ataupun karena ia mendapatkan pengalaman dari lingkungnganya. Pada fase ini dapat dilihat bagaimana perilaku conduct disorder subjek dalam berbiacara kotor. Pada kondisi satu bicara kotor anak berada pada rata-rata 11,12 pada kondisi kedua dan 11 pada kondisi kedua.

Implementasi dari desain multiple cross conditions yang digunakan oleh peneliti dilakukan pengamatan dalam 3 kondisi. Ketiga kondisi tersebut adalah kondisi kesatu yaitu pembelajaran pertama, kondisi kedua yaitu pembelajaran kedua dan kondisi ketiga yaitu pembelaran ketiga. Pengamatan dilakukan pada masing masing kondisi dengan frekuensi waktu 30 menit. Kondisi kesatu dilakukan dengan 6 sesi fase baseline dengan mengamati perilaku subjek ketika pembelaaran yang dilakukan oleh guru. Setelah fase baseline berlangsung selanjutnya adalah fase intervention dilakukan dengan penerapan pembelajaran teknik aversi berkondisi yang diberikan berdasarakan model pemberian hukuman decision making. 
Tabel 3 Jumlah Perilaku Conduct disorder Fase Multiple BaselineCross Condition Kondisi Ketiga

\begin{tabular}{lllll}
\hline \multicolumn{5}{c}{$\begin{array}{c}\text { Perilaku Conduct Disorder Fase Multiple } \\
\text { Baseline Cross Condition }\end{array}$} \\
\hline Fase & Sesi & $\begin{array}{l}\text { F re k u e n s i } \\
\text { Waktu }\end{array}$ & $\begin{array}{l}\text { Perilaku } \\
\text { Conduct } \\
\text { Disorder }\end{array}$ & $\begin{array}{l}\text { Rata- } \\
\text { Rata }\end{array}$ \\
& & & 10 & $' 11$ \\
\hline A & 1 & $11.00-11.30$ & 10 & \\
& 2 & $11.00-11.30$ & 18 & \\
& 3 & $11.00-11.30$ & 11 & \\
& 4 & $11.00-11.30$ & 11 & \\
& 5 & $11.00-11.30$ & 10 & \\
& 6 & $11.00-11.30$ & 10 & \\
& 7 & $11.00-11.30$ & 12 & \\
& 8 & $11.00-11.30$ & 9 & \\
& 1 & $11.00-11.30$ & 3 & \\
& 2 & $11.00-11.30$ & 5 & \\
& 3 & $11.00-11.30$ & 2 & \\
\hline
\end{tabular}

Gambar 1 Grafik Trend Jumlah Perilaku Conduct disorder

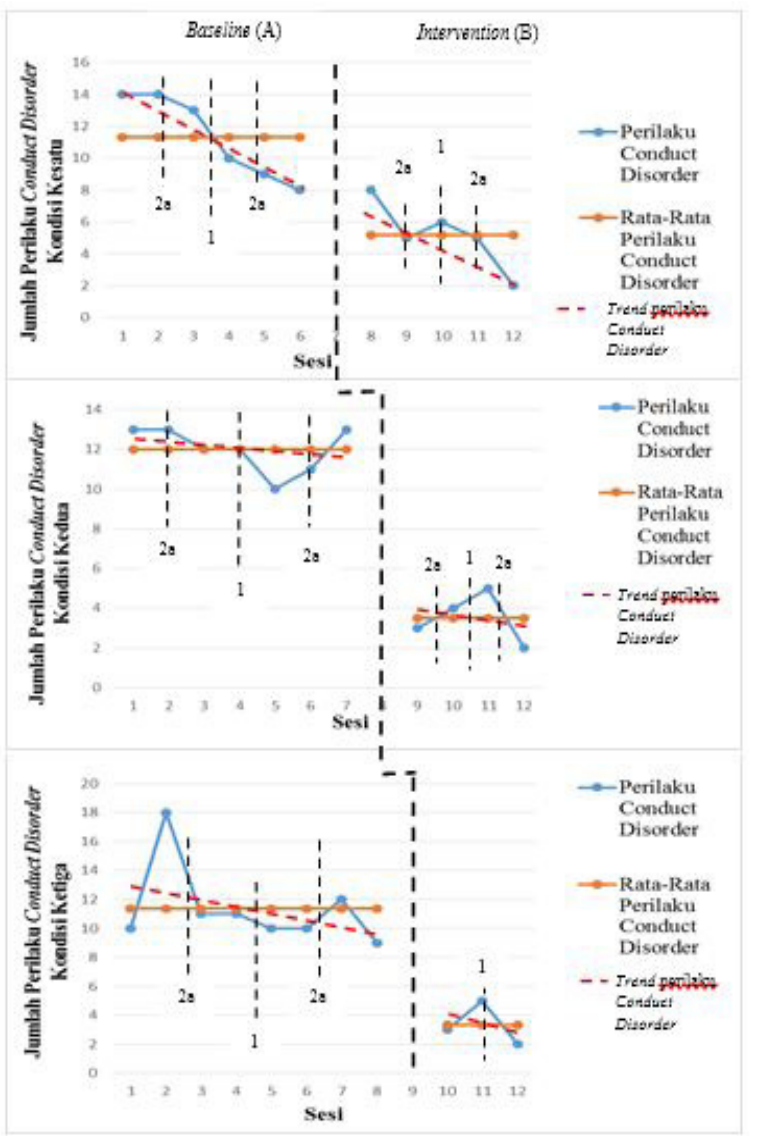

Saat kondisi kesatu masuk pada intevensi awal makan kondisi kedua masuk pada fase baseline sesi ketujuh. Sehingga dapat dikatakan bahwa kondisi dua fase baseline terdiri dari 7 sesi dan 4 sesi di fase intervesi. Ketika pda fase baseline kedua masuk pada fase intervention pertama maka kondisi ketiga masuk pada sesi kedelapan. Sehingga kondisi ketiga berjumlah 8 sesi untuk fase baseline dan 3 sesi untuk fase intervention. Pengamatan terhadap perilaku subjek dilakukan dengan pencacatan kejadian atau frekuensi dengan waktu yang konstan sesuai yang telah dijelaskan diatas. Pencatatan keadian menggunakan tally.

Rata-rata perilaku conduct disorder yang diperoleh subek pada fase baseline kondisi kesatu dan ketiga menunjukkan angka 11 sedangkan kondisi kedua menunjukkan angka 12 dalam waktii 30 menit. Berdasarkan pemaparan tersebut dapat terlihat bahwa perilaku subjek sebelum diberikan intervention masih sangtlah tinggi. Berdasarkan pendapat dari Rini (2010) mengemukakan bahwa salah satu penyebab terjadinya conduct disorder adalah karena fungsi kognitif atau pola pikir yang berhubungan degan fungsi intelgensi. Oleh karenanya, perilaku conduct disorder dapat muncul pada anak dengan hambatan intelektual dikarenakan mereka terhambat dalam pola atau cara berfikir.

Berdasarkan penelitian awal fase baseline itu digunakan sebagai penentuan untuk diberikannya intervention sesuai dengan kebutuhan siswa. Data ratarata fase intervention seteah diberikan treatment ratarata menjadi 5 untuk kondisi kesatu dan 3 untuk ratarata kondisi kedua dan ketiga. Hal itu menunjukkan adanya penurunan perilaku conduct disorder subjek.

Data rata-rata pada setiap fase baik baseline maupun intervention dilihat garis trend pada masing-masing kondisi. Garis trend pada masing masing kondisi kecendurungan turun kebawah pada setiap fasenya baik baseline maupun intervention. Perubahan level juga menunjukkan angka negatif pada setiap kondisi. Namun perubahan level pada kondisi kesatu menunjukkan nilai yang stabil Hal ini dikarenakan efektivitas dari intervention yang telah dilakukan belumlah berdampak signifikan terhada[ perubahan perilaku subjek. Namun, perolehan data perilaku subjek pada sesi terakhir di fase intervention menunjukkan angka dibawah 5 yang berarti teknik aversi berkondisi berdampak pada perilaku subjek.. Latency pada penelitian ini tidak nampak dikarenakan perilaku mengalami perubahan yaitu penurunan.

Berdasarkan pemaaran diatas, dapat diambil kesimpulan bahwa teknik aversi berkondisi efektif untuk mengubah perilaku conduct disorder subjek dengan hambatan tunagrahita. Hal ini dikarenakan pemberian hukuman akan mengakibatkan anak dapat berfikir bahwa perilaku yang dibuatnya akan menimbulkan dampak yang buruk yaitu dengan diberikannya hukuman secara verbal maupun non verbal. Sehingga subjek dapat sedikit demi sedikit mengendalikan dirinya. Sesuai dengan hasil penelitian Putra, dkk (2017) menyatakan bahwa teknik aversi 
efektif untuk menstabilkan self endurance siswa Singaraja karena dengan pemberian hukuman dapat menjadikan motivasi agar tidak mengulangi perbuatan yang dilakukan sebelumnya dimana self endurance adalah ketidakmampuan mengendalikan emosi.

Sejalan dengan penelitian yang dilakukan, menurut Soni Anggara (2010) dengan jurnal yang berjudul "Efektifitas Prosedur Aversi Untuk Mengurangi Perilaku Menyimpang Pada Anak Tunagrahita Ringan DI SLB Amal Bhakti Sicincin" menyatakan bahwa teknik aversi efektif dalam menangani perilaku meyimpang. Perilaku menyimpang dalam penelitian ini adalah perilaku onani dan teknik aversi yang dilakukan dalam penelitian ini adalah pemeberian balsam ketika anak berperilaku menyimpang. Pada penelitian ini menggunakan desain ABA dengan hasil persentase overlape yang semakin kecil menunjukkan adanya pengaruh perubahan pemberian teknik aversi untuk mengurangi perilaku onani subjek. Adapun pula penelitian yang dilakukan Karmila (2016) dengan judul "Mengurangi Perilaku Berkata Negatif Melalui Prosedur Aversi Pada Anak Autis X" teknik aversi berhasil mengurangi berkata negatif pada siswa autis $\mathrm{X}$ dengan mengucapkan istigfar setiap anak berkata negatif. Data hasil penelitian baik dalam ataupun antar kondisi menunukkan perubahan perilaku berbicara negatif subjek akibat dari pemberian intervensi menggunakan teknik aversi.

\section{KESIMPULAN DAN SARAN}

\section{Kesimpulan}

Penggunaan teknik aversi berkondisi untuk siswa tunagrahita dengan pemberian hukuman decision making yaitu pengkondisian kelas menunjukkan perubahan signifikan. Dapat dilihat dari hasil pengolahan data yang menunjukkan rata-rata fase baseline 11 kali untuk kondisi pertama dan ketiga serta 12 kali untuk kondisi kedua. Sedangkan pada fase intervention rata-rata menjadi 5 untuk kondisi pertama dan 3 untuk kondisi kedua dan ketiga. Diperoleh juga hasil perhitungan level berada pada nilai negative, trend menunjukkan penurunan dan latency tidak nampak dikarenakan hasil mengalami penurunan.

\section{Saran}

Diharapkan bagi pendidik untuk menerapkan dalam menangani perilaku menyimpang anak khususnya conduct disorder dengan cara teknik aversi berkondisi. Pemberian teknik aversi berkondisi ini dilakukan dengan menggabungkan dengan prosedur lainnya yaitu decision making (pengkondisian kelas) yaitu pembelajaran dilakukan dengan selalu melibatkan anak untuk aktif seperti mengkomunikasikan hasil pekerjaan di depan, mengerjakan tugas secara berkelompok, pemberin pembelajaran yang disisipkan melalui permainan. Teknik aversi berkondisi yang dilakukan yaitu dengan hukuman verbal dan non verbal. Pemberian hukuman dilaksanakan setelah anak berperilaku conduct disorder tanpa menunda atau ceramah.

\section{DAFTAR PUSTAKA}

Alberto \& Troutman. (2009). Applied Behavior Analysis ( ${ }^{\text {th }}$ Edition). New Jersey: Menrill Pearsion. Dari bookfi.org.

Anggara, S. (2017). Efektifitas Prosedur Aversi Untuk Mengurangi Perilaku Menyimpang Pada Anak Tunagrahita Ringan Di Slb Amal Bhakti Sicincin. E-JUPEKhu, 5(1)

Apriyanto, N. (2012). Seluk Beluk Tunagrahita \& Strategi Pembelajaran. Jogjakarta: Javaliter

Desinngrum, D. R. (2016). Psikologi Anak Berkebutuhan Khusus. Yogyakarta: Psikosain

Efendi, M. (2008). Pengantar Psikopedagogik Anak Berkelahinan. Jakarta: PT Bumi Aksara

Efendi, M. (2010). Pembinaan Bicara dan Bahasa. Malang: Universitas Negeri Malang

Gichara, J. (2006). Mengatasi Perilaku Buruk Anak. Jakarta: PT Kawan Pustaka

Karmila, Y., \& Iswari, M. (2017). Mengurangi Perilaku Berkata Negatif Melalui Prosedur Aversi Pada Anak Autis X. E-JUPEKhu, 5(2)

Mahabbati, A. (2014). Pola Perilaku Bermasalah dan Rancangan Intervensi pada Anak Tunalaras Tipe Gangguan Perilaku (Conduct Disorder) Berdasarkan Fungsctional Behavior Assesment. Dinamika Pendidikan, 21(01)

Purwanto, Edi. (2015). ,Modifikasi Perilaku Alternatif Penanganan Anak Berkebutuhan Khusus. Yogyakarta: Pustaka Belajar

Putra, I. D. G. A. P., MWP, D. A., \& Dharsana, I. K. (2017). Differences Effectiveness of Behavioral Counseling Modeling Technique with Aversi Technique to Self Endurance. Bisma The Journal of Counseling, 1(1)

Rini, I. R. S. (2010). Mengenali gejala dan penyebab dari conduct disorder. PSYCHOIDEA, 8(1)

Santrock, John. W. (2014). Psikologi Pendidikan. Jakarta: Harya Bhimasena

Tarigan, Henry Guntur. (2013). Menulis Sebagai Suatu Keterampilan Berbahasa. Bandung: Angkasa 